\title{
SYMBOL PRESERVATION AND IDENTITY OF GARUT CITY
}

\author{
Kunto Sofianto, Agusmanon Yuniadi, Agus Nero Sofyan, and Budi Gustaman
}

Department of History and Philology, Faculty of Cultural Sciences, Padjadjaran University, Indonesia

E-mail: kunto.sofianto@unpad.ac.id ; agusmanon@unpad.ac.id ;

agus.nero@unpad.ac.id; budi.gustaman@unpad.ac.id

\begin{abstract}
This article discusses the symbols and identity of Garut City, especially with regard to heritage buildings that were established since the Dutch colonial period. These buildings are very important to be maintained so that the identity of the Garut community is not eroded by the increasingly strong current of globalization. The research method used in this research is a qualitative research method with a historical approach. In addition, the concept of conservation is also used which refers to physical and non-physical aspects and adaptive re-use theory. The conclusion from this research is that various infrastructures, especially the buildings at the beginning of the establishment of Garut city are symbols and identities for the Garut people. The conclusion of this study is that the buildings are very important to be preserved so that they could be proud of by the people of Garut city or the people of Garut regency in general. Thus the Garut people will not lose direction in building a whole human. In addition, the Garut community will understand the importance of buildings in Garut city as a symbol or identity of the Garut community.
\end{abstract}

Keywords: Dutch Colonial; Garut; Identity; Preservation; Symbol.

\section{PELESTARIAN SIMBOL DAN IDENTITAS KOTA GARUT.}

\begin{abstract}
ABSTRAK. Tulisan ini membahas simbol dan identitas Kota Garut, terutama berkenaan dengan bangunan-bangunan heritage yang didirikan sejak masa kolonial Belanda. Bangunan-bangunan itu sangat penting untuk dipelihara agar jatidiri masyarakat Garut tidak tergerus oleh arus globalisasi yang semakin kuat. Metode penelitian yang digunakan dalam penelitian ini adalah metode penelitian kualitatif dengan pendekatan sejarah. Selain itu digunakan juga konsep konservasi yang merujuk kepada aspek fisik dan non-fisik dan teori adaptive re-use. Kesimpulan dari penelitian ini adalah bahwa berbagai infrastruktur, terutama bangunan-bangunan pada awal pendirian Kota Garut itu merupakan simbol dan identitas bagi masyarakat Garut. Kesimpulan dari penelitian ini adalah bahwa bangunan-bangunan itu sangat penting untuk dilestarikan sehingga dapat dibanggakan oleh masyarakat Kota Garut atau masyarakat Kabupaten Garut secara umum.. Dengan demikian masyarakat Garut tidak kehilangan arah dalam membangun manusia seutuhnya. Selain itu, masyarakat Garut akan memahami arti penting dari bangunan yang ada di Kota Garut sebagai simbol atau identitas masyarakat Garut.
\end{abstract}

Kata kunci: Garut; Identitas; Kolonial Belanda; Pelestarian; Simbol.

\section{INTRODUCTION}

Cultural heritage has various and broad meanings. This includes not only traditional and modern arts, performing arts, or language, but also urban building art that has grown and developed over decades or even hundreds of years. Inheritance (heritage) can be defined as something that is preserved from each generation to another, in the form of ideas, values, or objects. In general, heritage as an object can be categorized into three parts, namely a) Natural Heritage, which refers to natural or environmental wealth, b) Heritage Place, which refers to the built environment associated with society or activities in a cultural and economic context, and Cultural Heritage (cultural heritage), which refers to inheritance in the form of objects. It can be said that the decision to preserve and utilize ancient buildings was due, among other things, to the fact that the building had artistic value (building art / architecture, fine art, etc.) and was a cultural heritage object with historical value (Rubiantoro, 2018: 90).
Cultural Heritage can be classified into three types, namely:

1. Monuments and the environment, including architectural works, monumental sculptures and paintings, archaeological elements or structures, inscriptions, paintings in caves and their combinations which have universal value from the perspective of history, art and science.

2. Group of buildings and their environment, namely groups of separate or connected buildings due to architectural considerations and places or landscapes that have universal values that have universal values from the point of view of history, art and science.

3. Sites, namely human works or a combination of nature and human work, which include archaeological sites that have universal value from the point of view of history, beauty, ethnology and anthropology (Warjita, 2003: i-ii).

In analyzing the problem of preserving the symbols and identity of the City of Garut, the 
Adaptive Re-use Theory is also considered. Adaptive re-use is one way of building conservation efforts. In general, adaptive re-use is carried out as an alternative to protect and maintain historic buildings by transferring old functions into new functions that benefit the surrounding community and the area itself. This concept does not merely restore the physical appearance of architecture but seeks to respect and appreciate the historical value implied in it, the architectural style by transferring new functions that are more appropriate and useful. This will have a positive impact on the region itself and the local government. In its implementation, this concept experiences several different obstacles depending on the perceptions of the power holders in development and regional conditions. These constraints include the unresponsive attitude of planners who assume that old buildings are a barrier to economic progress because many old buildings are neglected and become obsolete. These buildings are considered outdated and unable to fulfill the demands of their present function. Because of this, some cities have even destroyed historical areas for the sake of new developments that are considered more appropriate and capable of improving community welfare. This actually sacrifices the original identity of the region (Sofiana, et al., 2014: 2)

This topic is very interesting to study because it fulfills two important aspects, namely the interested topic and the significance of the topic. With regard to two aspects, it should be discussed because Garut city was born during the British colonial rule under the leadership of Lieutenant Governor Raffles (1811 - 1816), then experienced the Dutch colonial era, the Japanese Occupation era and then the independence period of the Republic of Indonesia since 17 August 1945. With such conditions, creating a unique atmosphere in Garut city which is different from other cities in Priangan in particular. Since the Dutch colonial period, many buildings erected around the Garut square which constitute invaluable legacy or historical heritage. Even old building conservators in Indonesia, especially in West Java, are trying to save various buildings that are inherited from the past. The buildings, among others, are a legacy from prehistoric times, classical times and the Dutch colonial period. However, it is unfortunate that since 2007 the destruction of the legacy of the past, especially in the city of Garut, like buildings has become increasingly common. Even though these buildings are the identity characteristics (symbols) of Garut city which are not owned by other regions in Indonesia and of course are protected by law. The formulation of the problem in this research are:
1. When and how was Garut City born?

2. What are the symbols of Garut City as a personal identity?

3. Why does it need to be preserved?

\section{METHOD}

To understand the problem of preserving the symbols and identity of Garut city comprehensively and to answer them holistically, the authors use qualitative research methods and using a historical approach. Qualitative research explains a phenomenon in depth by way of collecting data as deep as possible, which shows the importance of depth and detail of the data under study. Qualitative research requires guidance in the formulation of substantive theories based on data (Moleong, 1997: $3)$. The historical approach is used to obtain primary data relating to the past of Garut city (Herlina, 2008: 17-60; Gottschalk, 1975: 80-116). The concept of revitalization refers to both physical and nonphysical aspects. The physical aspect includes the shape of the building, including its infrastructure, and the non-physical aspect relates to the socio-cultural and socio-economic problems of the people living around the preserved buildings. This is intended so that the existence of buildings and their preserved areas could have a positive impact on improving people's lives and the environment (Purwantiasning, 2015: 5).

\section{RESULTS AND DISCUSSION}

\section{Early Establishment of Garut City}

In 1811, the district of Limbangan (nowadays Balubur Limbangan district) was abolished by Daendels on the grounds that coffee production from the Limbangan area decreased to the lowest point (zero) and its regent, Tumenggung Wangsakusumah II, was dismissed for refusing orders to plant indigo. The two reasons were reasonable for Daendels to abolish the Limbangan Regency because it was considered not to support his government (Anggapradja, 1979: 113 and Surianingrat, 1985: 187). On 16 February 1813, Raffles as Lieutenant Governor in Indonesia issued a Decree regarding the re-establishment of Limbangan regency with its capital city Suci (Raffles, 1813: 1). Suci as the capital of Limbangan regency does not fulfill the requirements, because of its location and narrow area for city expansion. Therefore, the regent of Limbangan Adipati Adiwijaya (1813-1831) formed a committee to find a suitable place for the district capital. At first the committee found a place $\pm 3 \mathrm{~km}$ to the east of Suci area, namely Cimurah, which had a 
land suitable to be used as a capital. However, because in that place clean water was difficult to obtain, the area was canceled. Until now this place is called Kampung Pidayeuheun (Anggapradja, 1979: 7).

Then the committee looked for a place to the west from Suci, $\pm 5 \mathrm{~km}$, and found a suitable place to be used as the capital. Apart from being flat, fertile, and having springs whose water continues to flow into the Cimanuk river, this place also has a beautiful view that is surrounded by mountains, including Mount Cikuray, Mount Papandayan, Mount Guntur, Mount Galunggung, Mount Talaga Bodas, and Mount Karacak. When the committee found a spring (small lake) covered with thorny shrubs (marantha), one of the committee members had scratched his hand until he bled. When examining and fixing the place also came a European (Dutch), who when he saw someone's hand was bleeding, he asked "why is it bleeding". The person who was scratched said that he was kakarut (scratched). The Dutchman imitated the word, and because his tongue was not fluent, he called "gagarut" (Anggapradja, 1979: 7).

Since then the workers who participated in the committee group named the thorny plants as " $\mathrm{Ki}$ Garut" and the lake was also called "Ci Garut". The location of the spring and lake " $\mathrm{Ci}$ Garut" is now occupied by the buildings of SMP I, SMP II, and SMP IV (Anggapradja, 1979: 7). With the discovery of Ci Garut, the area around the place was known as Garut. The spark of the word arrowroot turned out to be approved by the regent of Limbangan Regency, Adipati Adiwijaya, who named the place to be the capital of Limbangan regency as Garut.

On September $15^{\text {th }} 1813$, the first milestone were laid to build the capital's facilities and infrastructure, namely the residence, the regent's office, and the pavilion (pendopo), the office of the Assistant Resident, a mosque, a prison and a square surrounded by these places above. In front of pendopo or between the square and pendopo, there is a babancong which is a place, especially for speeches by regents or other government officials in front of the public. Although the development of city facilities and infrastructure was under local authority (in this case the regent), however in its implementation, it was inseparable from the colonial city arrangement because at that time Garut was under British colonial rule and subsequently the Dutch colonial government. It can be said that the early development of cities in Indonesia during the colonial period was characterized by colonial cities (Makkelo, 2017: 87). After these places were completed, the capital of Limbangan regency moved from Suci to Garut around 1821. The legacy of the former capital of Limbangan Regency in the Suci area since 1973 is occupied by SD Parabon I and II Karangpawitan. From 1963 to 1982, September $15^{\text {th }} 1813$ was made the Anniversary of Garut. The date, month and year refer to the writing written on the Leuwidaun (Cimanuk) bridge before it was renovated (Sofianto, 2001: 24).

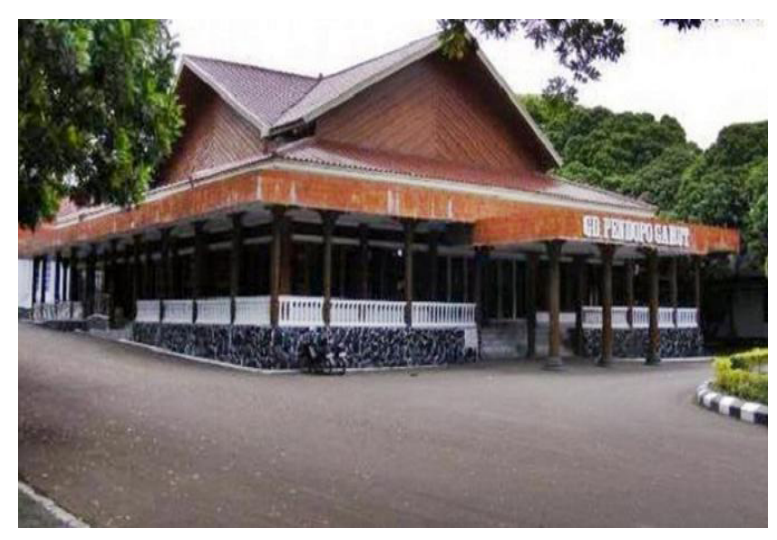

Source: https://www.google.com search?q=pendopo + garut + images $\&$ safe Accessed on February, $14^{\text {th }}$ 2021

\section{Figure 1. Pendopo of Garut Regency}

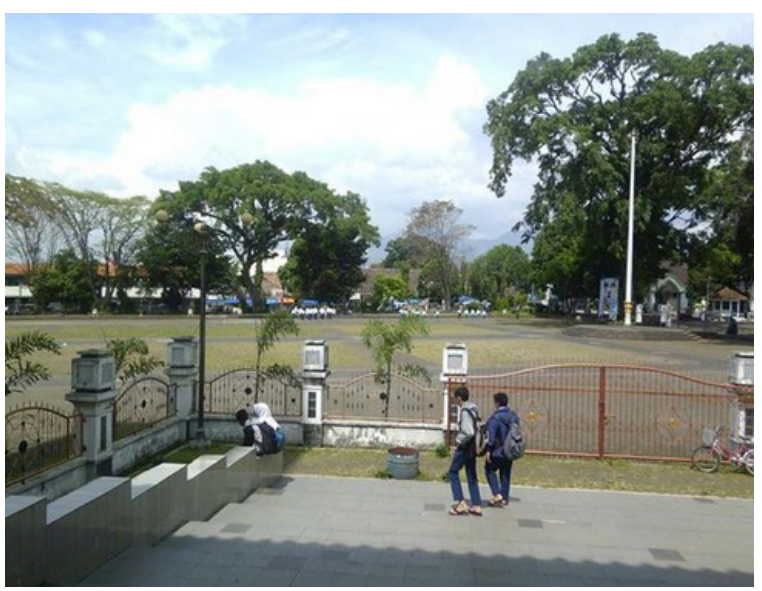

Source: https://www.google.com/search?q=foto+alunalun + garut\&safe $=$ Accessed on February, 14 ${ }^{\text {th }} 2021$

Figure 2. The Square of Garut Regency

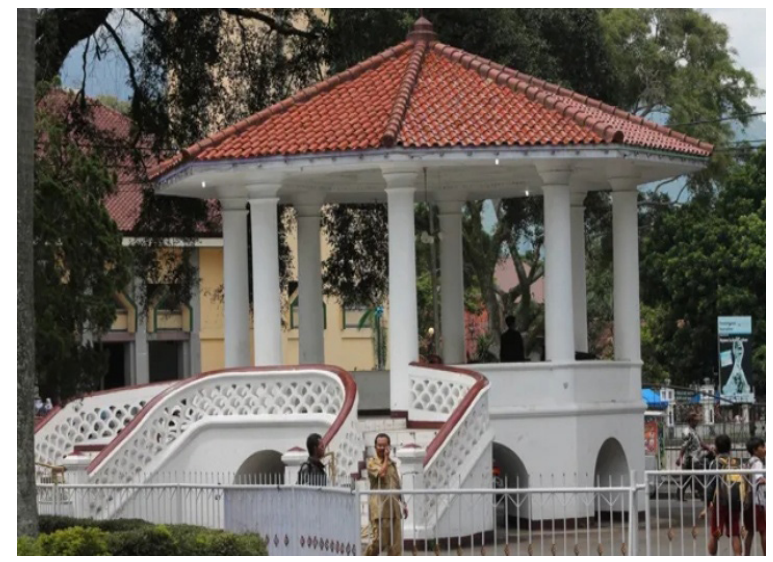

Source: https://www.google.com/search?q=foto+alunalun+garut\&safe Accessed on February, $14^{\text {th }} 2021$

Figure 3. Babancong of Garut Regency 


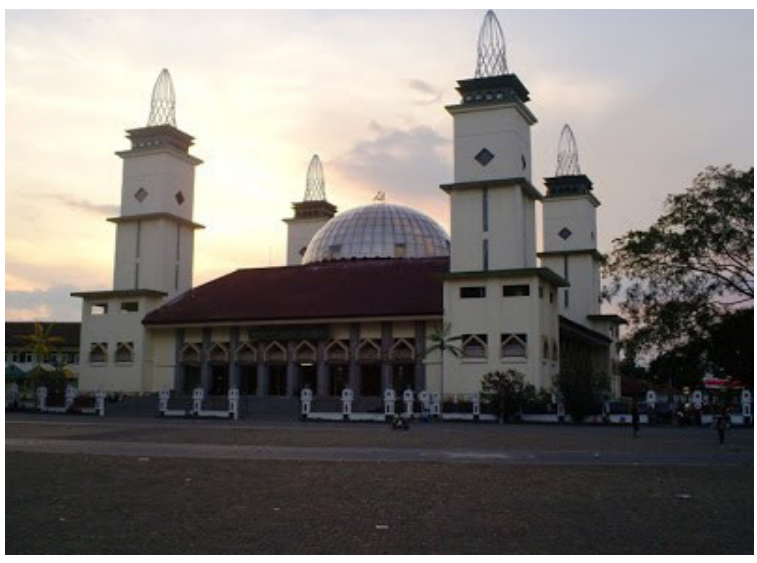

Source: https://indrakh.wordpress.com/2008/09/12/masjid-agunggarut- saksi-bisu-sejarah-kota/ Accessed on February, 14 ${ }^{\text {th }} 2021$

Figure 4. Great Mosque of Garut Regency

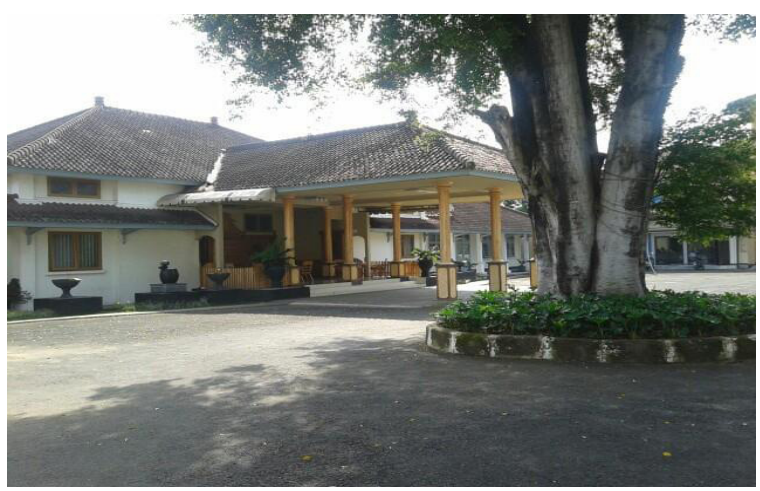

Source: https://foursquare.com/v/bakorwil-priangan/4dd372f4 45dd98b61e6d68a4?openPhotoId=53fd52ed498e16f8cd111 fce Accessed on February, $14^{\text {th }} 2021$

Figure 5. The former Resident Assistant building. Nowadays the Bakorwil Building

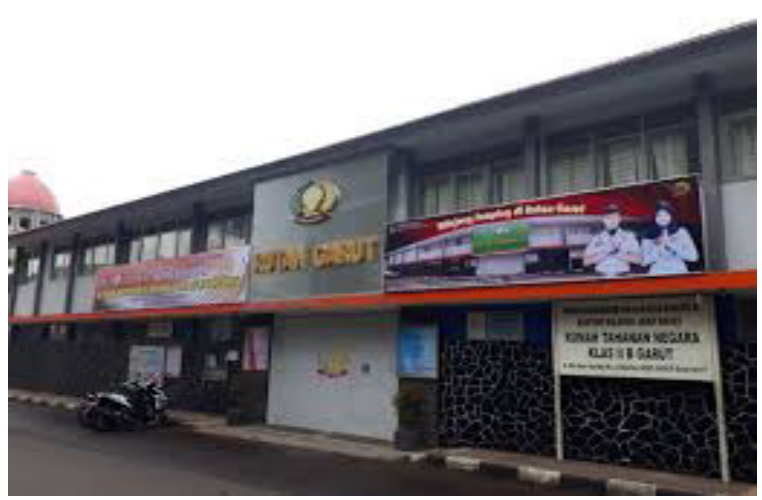

Source: Yasonna Laoly : Lembaga Pemasyarakatan (lapas) dan Rumah Tahanan (rutan) di Indonesia Sangat Buruk - WARTA

SIDIK Accessed on February, $14^{\text {th }} 2021$

Figure 6. The Prison of Garut Regency

On July $1^{\text {st }} 1913$, based on the Governor General Decree May $7^{\text {th }} 1913$ Number 60 (Sofianto, 2001: 11)), the name of Limbangan Regency was changed to Garut regency with its capital Garut. Garut city at that time included three villages namely Kota Kulon village, Kota Wetan village, and Margawati village (Anggapradja, 1979: 160-161). The Garut Regency includes the districts of Garut, Bayongbong, Cibatu,
Tarogong, Leles, Balubur Limbangan, Cikajang, Bungbulang, and Pameungpeuk (Surianingrat, 1985: 218).

The physical development of Garut City from the early to the 1960 s can be divided into three periods (Falah, et al. 2017: 6), namely the first period (1813-1920) developed linearly. At that time, after the opening of the city of Garut, many buildings were built by the Dutch colonial government regarding government interests, investment in plantation businesses, the extraction of mineral materials, and tourism objects. Residential groupings are mainly located around the square and extend eastward along Jl. Societeit Straat. The second period (1920-1940), its development changed from linear to concentric. The changes were caused by existing projects in the first period that were able to provide services to residents. During that period, changes in the face of urban planning began to appear to change with the establishment of various city facilities, including train stations, post offices, drugstore, schools, hotels, shops (shops owned by Chinese, European, Japanese, Arab, and Indian. ), and markets. After the construction of various city facilities, Garut City developed not only as a center of government, but also as a center for education, economy, and tourism. In the third period (1940 - present), the development of the city of Garut tends to follow a multiple core theory. This development can be seen in the trade, education and settlement zones due to population growth (Sofianto, 2001: 11-12).

The interesting one during the Dutch Colonial Government was the opening of plantation areas and tourism spots. The plantation areas are in Giriawas, Cisaruni, Papandayan, and Darajat. Then between 1900 and 1928, tea, rubber and quinine plantations were opened again, owned by private entrepreneurs from Holland, England, Italy, Germany, and China. The plantations are located in the Cilawu, Cisurupan, Pakenjeng, Cikajang, Cisompet, Cikelet, and Pameungpeuk areas (Sofianto, 2001: 14)

The opening of the plantation areas was also followed by the construction of hotels in the City of Garut and the surrounding areas as a means of accommodation and entertainment for planters or tourists (especially from abroad). Hotels in the city of Garut are Papandajan Hotel, Hotel Vila Dolce, Hotel Belvedere, and Hotel Van Hengel (Sofianto, 2014: 52). Outside the city of Garut, namely Hotel Ngamplang in Cilawu, Hotel Cisoeroepan in Cisurupan, Hotel Speeding in Tarogong, Hotel Bagendit in Banyuresmi, Hotel Kamodjang in Samarang, and Hotel Cilaut Eureun in Pameungpeuk. Apart from recreation areas in plantation areas, other 
places are also opened for tourism. Those places are Papandayan Crater, Kamojang Crater, Manuk Crater, Telaga Bodas Crater, Bagendit lake, Cangkuang lake, Cipanas (hot spring baths), Cikuray Mountain, Guntur Mountain, and Pameungpeuk Beach. (In Note). The foreign tourists who came to the City of Garut at that time, namely from America, England, Australia, the Netherlands and Japan. Important and famous people who have come to Garut city are King Leopold and his Empress Astrid, movie star Charlie Chaplin staying at Hotel Ngamplang, Renate Muller, and Hans Albers. Then, Susuhunan Pakubuwono $\mathrm{X}$ also visited Garut city and stayed at the Hotel Papandayan (Drissen, 1983: 13-14).

By Seeing the progress of tourism in Garut, Soeria Kertalegawa as Garut regent initiated a meeting for the formation of Vereeniging Mooi Garoet (Association of wonderful Garut) on February $14^{\text {th }} 1934$. The meeting was attended by, among others, Sangster as Resident Assistant and chairman of Vereeniging Bandoeng vooruit (Association of Advanced Bandung), Hoogland. (Sunjayadi, 2019: 166).

\section{Preservation of Symbols and Identity of Garut City}

According to the writer, there are three factors why the authenticity of the city which is also a symbol and identity of Garut city is difficult to preserve. This can be studied from the perspective of the building, space, and sense of belonging of the Garut city residents themselves. In the perspective of building and space, there are buildings and spaces of the past (especially the Dutch colonial period), the present space (after the independence of the Republic of Indonesia in 1945), and the future. The buildings and spaces of the past, especially from the early days of the city of Garut until before the independence of the Republic of Indonesia in 1945 could be said to characterize the identity of Garut city. Its boundaries are around Garut Kota District and part of Tarogong District (Van Dyck, 1922: 48).

Its symbols include the main square, pavilion (Pendopo) and residence of the regent, babwisata, mosque, prison, resident assistant building (now Bakorwil Priangan). In addition, Office of Garut Kota District (Jl. Pramuka) 14), building of Garut Railway Station (at the end of Jl. Bank and Veteran), building of Post Office (A. Yani street number 40), building of Bank Jabar, prior to demolition (A. Yani street number 38), Headquarters Kodim 0611 (Veteran street number 1), Korem Headquarters 062 Tarumanagara (Bratayuda street number 65), building of Disparbud (Ciledug street number 120), building of Garut General Hospital (Rumah Sakit Umum street number 10), residential home of $\mathrm{H}$. Ayo Tjumara (Ranggalawe street number 2), the house of the Pastor and the Catholic Church (Bank street number 50), the house of the Protestant Christian Church Pastor (Bratayuda street number 40), building of the Seventh Day Adventist Church (Pramuka street number 4), building of Negeri Regol I and II (Bratayuda street number 48), building of SDN Regol VII and X (Ranggalawe street number 7), building of SDN Kota Kulon I and II (Ciledug street number 205), building of Vihara Dharma Bakti (Guntur street number 120), building of KNPI (A. Yani street number 28), the Tenjolaya Tomb gate (Kerkhop), and building of PTG (Garut Weaving Factory). In essence, the symbol of the city of Garut is a building that existed before the 1945 Indonesian independence (Warjita, 2003: 6-28)

Unfortunately, some symbols of Garut city are not preserved so that they become damaged, altered, or deliberately damaged by certain individuals who seek mere material gain.

There is an assumption that the conservation building is seen as an ancient building that has no value and is no longer in accordance with modernism so that it is often the target of demolition (Rahadian and Wilianto, 2019: 41). The management of historical buildings currently faces several problems, such as the occurrence of function changes, physical changes/ building designs, neglect, and the absence of regional regulations that regulate the protection of cultural heritage objects (Akbar and Wijaya, 2008: 14).

Buildings that are not maintained, for example the building of Garut Railway Station before renovation in 2019. Building which have been changed, for example Babancong, building which were damaged, for example the Garut Weaving Factory (PTG), the environment around the Jayaraga field which in the Dutch colonial era was a horse racing place now had many irregular houses built, the Padang Boelan building was destroyed and replaced by a new building used by Bank Jabar, and building which was renovated without considering the architecture of the original building, namely the Great Mosque of Garut. A good example of preserving the Great Mosque is in Serang Banten Regency because the Grand Mosque was renovated without losing its original identity. The destruction of these ancient-historic buildings is the same as erasing one of the history and traditions of the past. The loss of ancient buildings is also a part of the history of a place that has actually created an identity of its own, causing an erosion of cultural identity (Kurniawan and Arthana, 2018: 91). 
The former PTG building, for example, according to the writer's opinion, could be revived as a factory which is useful and could absorb thousands of workers. Or it could be used as a place for other positive activities by maintaining the authenticity of the PTG building. It should be noted that the PTG during the Dutch colonial era was called Preanger Bont Weverij. From its inception in 1933 to 1942, it was the largest weaving factory in Southeast Asia, producing "Asian" patterned fabrics called Madras cloth, paddy sarong and Turkey Towel stamped towels. Apart from being marketed throughout the Dutch East Indies (the name of Indonesia during the Dutch colonial period), these products were also exported, especially to Asian countries, such as Singapore, Malaysia, India, Sri Lanka, Thailand and Vietnam. This building as a symbol of Garut City keeps many memories or struggles for Garut city residents against the Japanese army in October 1945 (Sofianto, 2001: 35).

In addition, if the local government of Garut wants to preserve the cultural heritage of the Garut city, it must involve the participation of the competent Garut community to discuss it. After the PTG building is destroyed and turned into a Mall, the incident will repeat itself, namely the Mall building will be destroyed in the future too. Likewise, the Padang Boelan building was destroyed to be occupied by Bank Jabar, so the Bank Jabar building in the future will also be demolished for reasons of expansion or not in accordance with the times. The incident will continue, future generations who are irresponsible (narrow-minded) will destroy each other because the struggle for material imitates the previous generation. Should irresponsible people continue to destroy the identity and symbol of Garut city for the sake of mere material gain? Can't people think of looking for "legal" material without destroying the identity and symbol of Garut city? The writer makes an analogy that if a child does not have an identity and does not know their origins (especially father and mother), the child could be called an "illegitimate child" and is vulnerable to being bullied.. Likewise with a city, if it does not know the origins and does not have an identity, then the city will be called a "illegal city" which is easily disturbed and tormented. Of course this will be very dangerous for next generations in the future. Therefore, the symbol of the city as proof of identity is very important so that in the future generations are not "dazed" and understand its origins. An urban area needs to pay attention to historical heritage as an effort to use resources in the spatial dimension to achieve a better urban area. Urban physical development without paying attention to existing inheritance in terms of buildings, areas, community structures and others, will change the face of the city so that the values embedded in a city will be lost (Bramasta, et al. 2015: 68)

According to the writer's opinion, if the local government is aware of and understands the importance of symbols and identities for the young generation of Garut in the future, it will certainly preserve the heritage of the past culture which is actually protected by the law. There is a saying from developed countries, namely "The man who controls the past surely will control the future". But unfortunately, many people "blind themselves" so that "self-identity" is also sacrificed. This of course will raise big questions in the future, "who destroyed the symbol and identity of Garut city? In this case, history will judge their actions in the future. Cultural conservation in the form of objects, buildings, structures, sites and areas needs to be managed by local governments by increasing community participation in protecting, developing and utilizing these cultural heritage. With the change in the paradigm of cultural heritage preservation, it is necessary to balance ideological, academic, ecological, and economic aspects in order to improve people's welfare (Panggabean, 2014: 26).

As we know that penetration of foreign cultures to local cultures that maneuver with the strong development of technology today is a necessity for the Indonesian people. This fact cannot be denied or even avoided by all levels of society in any region (Azis, et al., 2020: 356). In terms of cultural preservation, the Garut Regional Government should emulate developed countries, among others, European, American, Japanese, Korean, and Malaysian countries. These countries maintain the culture of the past physically and non-physically so that they know their own identity in the future so that future generations will not lose direction in building their country. Sustainable development' is really important to safeguard the longterm interests of the planet and its many life forms. It is about addressing social, environmental, and economic issues in an integrated way, meeting present needs without compromising the ability of future generations to meet theirs (Rodwell, 2003: 58).

In spatial planning, Garut Regional Government must be able to make "participatory planning" by including city residents so that the existence of space as part of the past is maintained. Thus spatial planning for the present and future will create a balanced pattern of urban development between the perspective of the past and perspectives of the future. Heritage provides a classic pride, color and grandeur 
that cannot be valued in money, while a city that has a future perspective will make a place suitable to the demands of the times.

The local government of Garut could consider the space requirements for the present or future to the North, South, or West so that various centers of activity will not overlap with heritage buildings and spaces as symbols of Garut city. In addition, the center of people activities will not be concentrated around the district of Garut Kota. Thus the development of the city will be built in well-balanced. Cultural heritage has values of past cultural heritage that must be preserved and maintained in order to support urban development in the future (Fanani and Kurniati, 2018: 7)

From the perspective of a sense of belonging, there are indigenous groups, immigrants, and business people, and the local government of Garut regency. For the indigenous people of Garut in general, a sense of belonging to the Garut city is embedded in their hearts so that the feeling of wanting to preserve the symbols of Garut city is definitely strong. However, because they do not have the strength to voice it, they are apathetic and no longer have pride of Garut city symbols. For the immigrants in general, a sense of belonging to the Garut city is not embedded in their hearts, so the feeling of wanting to preserve the Garut city symbols is definitely not strong, because the most important thing for them is that they could live in Garut city without thinking about the identity of where they live. For business people, especially contractors as "destroyers" of buildings as symbols of Garut city, they do not have sense of belonging to the Garut city. The most important thing for them is to get as much material gain as possible without thinking about identity of Garut city. This group, according to the writer, is a group of "brokers" who will "kill the character" and destroy the identity of Garut city so that the next generation of Garut will lose direction in finding the concept of development in the Garut city. Even worse, maybe future generations will imitate the negative actions of the previous generation. Of course this must be realized by the Garut Regional Government about the capitalistic businessman's actions. As far as possible, the authorities should be able to prevent it so that the symbol and identity of the Garut city which is invaluable with money could be preserved.

For Garut local government, the sense of belonging to the Garut city is really strong, although some of them do not come from Garut because they are the ones who make the concept of environmentally development. The thing that the writer is worried about, as what has happened with the destruction of the symbolic buildings of Garut city is that there are some of apparatus who collude with contractors so that the development concept of Garut city that has been made in the form of Garut City Planning is at a cost tens of millions of rupiah is redundant. In addition, do not assume that the Garut people are only good at destroying their own rather than preserving them. According to twriterr's opinion, whoever sits as the executive, legislative, or judiciary, what is important thing is that they are concerned and have spiritual intelligence in maintaining the cultural heritage that becomes the identity and symbol of Garut city.

There are several dimensions in seeing the importance of cultural heritage, namely the dimensions of knowledge, ethnicity, aesthetics, and the public. In the knowledge dimension, cultural heritage is used as a medium for recitation and academic testing. In the ethnic dimension, cultural heritage has a position as part of the identity and life background of a nation. From an aesthetic point of view, cultural heritage is a proof of great artistic results. Then in terms of the public, cultural heritage has educational value for the community, as a tourist attraction, as well as a vehicle to benefit economically (Sodiq, et al., 2018: 7).

\section{CONCLUSION}

The birth of Garut City coincided with the establishment of Limbangan regency which was later called Garut. On February $16^{\text {th }} 1813$, Raffles as Lieutenant Governor in the Dutch East Indies issued a Decree regarding the re-establishment of Limbangan regency with its capital city in Suci. Because Suci area as the capital of Limbangan regency did not meet the requirements, the Regent of Limbangan, Adipati Adiwijaya (1813-1831) formed a committee to find a suitable place for the district capital. Initially, the committee found a place $\pm 3 \mathrm{~km}$ to the east of Suci area, namely Cimurah, which had a suitable land as a capital city. However, because in that place clean water was difficult to obtain, the area was canceled. Finally the committee found a suitable place for the district capital to the West of Suci \pm 5 $\mathrm{km}$. The place was near a small lake which was later called " $\mathrm{Ci}$ Garut". The spark of the word arrowroot was approved by the Regent of Limbangan regency, Adipati Adiwijaya, who named the place to be the capital of Limbangan regency as Garut. Since 15 September 1813, facilities and infrastructure were built for the capital. After these places were completed, the capital of Limbangan regency moved from Suci to Garut around 1821. On July $1^{\text {st }} 1913$, 
the name of Limbangan regency was changed to Garut regency with its capital Garut. Symbols of the City of Garut, including the residence, the regent's workplace, and the pavilion, the Assistant Resident's office, the grand mosque, the prison, the square, and babancong. In addition, also the Garut Kota sub-district office building, Railway Station building, Post Office building, Kodim Headquarters building 0611, Disparbud building, General Hospital building, SPM Catholic Church Pastor building, Protestant Christian Church Pastor building, Holy Virgin Catholic Church building, building The 7th Day Adventist Church, the Dharma Bakti Temple building, and the Tenjolaya Tomb Gate (Kerkop) building. Preservation of old buildings in Garut city as a heritage is very important. The reason is, so that people today and the future know the history of the birth of Garut city. Thus, the character of the city and its people will be maintained continously. This will have a positive impact on development in the Garut city, where the buildings of the past will be created as a legacy of the past and modern developments needed by the people of Garut City. Of course, the preservation of the symbol of the Garut city requires the cooperation of various parties, including the community, government, and stakeholders to direct the development of of Garut city in its various dimensions so that its growth could be beneficial for present and future people, comfortable to live in and become pride of the Garut community.

\section{ACKNOWLEDGMENTS}

Alhamdulillah, we praise and thank God Almighty for the abundance of His mercy and grace. Our gratitude goes to the Rector of Unpad, Director of DRPMI/LPPM Unpad, Dean of FIB Unpad, Mariska FIB Unpad, and Head of the Department of History and Philology, Faculty of Culture Science Universitas Padjadjaran, who have given enthusiastic support for our research to run well and smoothly. Thank you also to all those who have helped us to materialize this article. Hopefully the kindness of you will be rewarded with kindness in kind by God Almighty. Amen!

\section{REFERENCES}

Akbar, R. \& Wijaya, I.K. (2008). Manajemen Aset Sebagai Upaya Pelestarian Bangunan Bersejarah di Kota Bandung. Jurnal Perencanaan Wilayah dan Kota, 19, (1), 13-33.

Azis, A; Komalasari, K; and Masyitoh I.S.(2020) "Strengthening Young Generation Characters
In The Disruption Era Through The Internalization of Wayang Golek Values" in Sosiohumaniora, 22, (3), 356-364.

Anggapradja, S. (1979). Sejarah Garut dari Masa ke Masa, Garut: Pemerintah Dt. II Garut.

Bramasta, D., Rindarjono, M. \& Sarwono. (2015). Proses Keruangan Pelestarian Saujana Budaya Kota (Urban Heritage) di Kecamatan Laweyan Kota Surakarta tahun 2013 (Kajian Pelestarian Cagar Budaya Di Kecamatan Laweyan Kota Surakarta). Jurnal GeoEco, 1, (1), $67-82$

Raffles, T.S.B. (1813). Extract from the Proceedings of the Honorable the Lieutenant Governor in Council, in the Public Department. Batavia,The 16th February, 1813.

Falah, M., Herlina, N. \& Sofianto, K. (2017). Morfologi Kota-kota di Priangan Timur pada Abad XX - XXI; Studi Kasus Kota Garut, Ciamis, dan Tasikmalaya, Jurnal Patanjala, 9, (1), 1-14.

Fanani,F.\& Kurniati,A.C.(2018). Upaya Pemerintah dalam Melestarikan Urban Heritage dalam Mendukung Liveable City Kota Yogyakarta. Jurnal KURVATEK, 3, (2), 7-14.

Gottschalk, L. (1975). Mengerti Sejarah. Terjemahan Nugroho Notosusanto, edisi ke-2. Jakarta: Yayasan Penerbit Universitas Indonesia.

Herlina, N. (2008). Metode Sejarah. Bandung: Satya Historika.

Indra (2008). "Masjid Agung Garut", dalam https:// indrakh.wordpress.com/2008/09/12/masjidagung-garut-saksi-bisu-sejarah-kota/. Accessed on February, 14 2021.

Kurniawan, A \& Arthana, N.N. (2018). Preservasi dan Konservasi Fasade Bangunan Kolonial di Jalur Belanda Kota Singaraja Bali untuk Pelestarian Kawasan Kota Lama. UNDAGI: Jurnal Ilmiah Arsitektur, 6, (2), 90-96.

Makkelo, I.D. (2017). Sejarah Perkotaan: Sebuah Tinjauan Historiografis dan Tematis. Jurnal Lensa Budaya, 12, (2), 83-101.

Moleong, Lexy. (1997). Metodologi Penelitian Kwalitatif. Bandung: PT Remaja Rosda Karya.

Nugroho, A. (2021). "Alun-alun Garut", dalam https://ihategreenjello.com/pesonakeindahan-obyek-wisata-alun-alun-3/. Accessed on February, 14 2021. 
Panggabean, S.A. (2014). Perubahan Fungsi Dan Struktur Bangunan Cagar Budaya Kota Semarang Ditinjau dari Perspektif UndangUndang Nomor 11 Tahun 2010. Unnes Law Journal, 3, (2), 24-33.

Purwantiasning, A. W. (2015). Kajian Revitalisasi pada Bantaran Sungai sebagai Upaya Pelestarian Bangunan Tua Bersejarah. Studi Kasus: Kawasan Malaka, Malaysia. Makalah dalam Prosiding SNTT FGDT 2015 ISSN: 2339-028X. Fakultas Teknik Universitas Muhammadiyah Makassar (30 Juli-2 Agustus 2015).

Rahadian, R.G.N. \& Wilianto, H. (2019). Kajian Konservasi Bangunan Melalui Unsur Pembentuk Arsitektur Dalam Upaya Pelestarian Bangunan Tua Di Kota Bandung Studi Kasus : Gedung Panti Karya, Jalan Merdeka no. 39 Bandung, Jawa Barat. Jurnal IDEALOGIde dan Dialog Indonesia, 4, (1), 40-52.

Rodwell, D. (2003). Sustainability and the Holistic Approach to the Conservation of Historic Cities" in Journal of Architectural Conservation, 1, 58-73.

Rubiantoro, E.A. (2018). Kajian Konservasi Bangunan Cagar Budaya pada Koridor Jl. Kepodang Kota Semarang. Jurnal Riptek, 12, (I), 89-96.

Sodiq, I., Saraswati U. \& Prabowo, A. (2018). Pengembangan Model Konservasi Kesejarahan di Semarang Berbasis Teknologi Informasi. Indonesian Journal of Conservation, 07, (02), 99-110.

Sofiana, R., Purwantiasning, A.W. \& Anisa. (2014). Strategi Penerapan Konsep Adaptive Re-Use Pada Bangunan Tua Studi Kasus: Gedung Pt P.P.I (Ex. Kantor Pt Tjipta Niaga)Di Kawasan Kota Tua Jakarta. Jakarta: Seminar Nasional Sains dan Teknologi 20141 Fakultas Teknik Universitas Muhammadiyah Jakarta.

Sofianto, K. (2001). Garoet Kota Intan Sejarah Lokal Kota Garut Sejak Zaman Kolonial Belanda Hingga Masa Kemerdekaan. Sumedang: Alqaprint Jatinangor.

Sofianto, K. (2014). Garut pada Masa Pemerintahan Pendudukan Jepang (1942-1945), Sosiohumaniora, 16, (1), 51-61.

Sunjayadi, A. (2019). Pariwisata di Hindia Belanda (1891-1942). Jakarta: Grafika Mardi Yuana.

Surianingrat, B. (1985). Pustaka Kabupatian i Bhumi Limbangan Dong Garut. Bandung.

Van Dyck, J. Z. (1922). Garoet en Omstreken Zwertochten door De Preanger. Batavia: G, Kolff \& Co.

Wartasidik (2019). "Rutan Garut", dalam Yasonna Laoly : Lembaga Pemasyarakatan (lapas) dan Rumah Tahanan (rutan) di Indonesia Sangat Buruk - WARTA SIDIK

Warjita. (2003). Dokumentasi Bangunan Warisan Budaya Kabupaten Garut. Garut: Cendikia Garut. 